ЕПХИЕВ Олег Муратович - кандидат социологических наук, старший преподаватель департамента социологии факультета социальных наук и массовых коммуникаций Финансового университета при Правительстве РФ (125993, Россия, ГСП-3, г. Москва, ГСП-3, Ленинградский пр-кт, 49; ephiev@fa.ru)

ДАВИДЕНКО Валерия Алексеевна - студентка факультета социальных наук и массовых коммуникаций Финансового университета при Правительстве РФ (125993, Россия, г. Москва, ГСП-3, Ленинградский пр-кт, 49; davidenko.valeriya@list.ru)

\title{
ДЕВИАНТНОЕ ПОВЕДЕНИЕ ИНДИВИДА В РЕЗУЛЬТАТЕ ВЗАИМОДЕЙСТВИЯ С МИКРОФИНАНСОВЫМИ ОРГАНИЗАЦИЯМИ
}

\begin{abstract}
Аннотация. В статье рассматриваются определенные риски взятия займов в микрофинансовых организациях при условии возникновения финансовых потрясений. Вопрос о последствиях микрозаймов является актуальным, поскольку они могут привести к различным формам девиантного поведения индивида, существенно влияющего на социально-экономическую ситуацию в обществе.

Ключевые слова: девиантное поведение, кредитные займы, микрофинансирование
\end{abstract}

$\mathrm{H}$ а сегодняшний день на рынке финансовых услуг в России стремительно развивается микрофинансирование, занимая важную позицию в решении социально-экономических проблем. Микрофинансовая деятельность способствует поддержке малообеспеченного населения, сокращая уровень бедности путем вовлечения их в экономические процессы страны, а также предприятий малого бизнеса - тех, кто в первую очередь сталкивается с трудностями получения кредитования в других финансовых учреждениях [Криворучко и др. 2013].

Бедность в России является актуальной проблемой. По данным Росстата, на 29.04.2020 численность населения с денежными доходами ниже величины прожиточного минимума составляет $12,3 \%$ общей численности населения за 2019 г. ${ }^{1}$ У граждан с низким доходом нет возможности обращения к традиционным финансовым институтам, но есть доступ к микрофинансовым организациям. Таким образом, бедность является одним из факторов обращения населения в микрофинансовые организации.

Микрофинансовые организации продолжают свое развитие в стране. На данный момент микрозаймы доступны даже людям без кредитной истории или с плохой кредитной историей, тем самым позволяя получить доступ к банковским услугам [Криворучко и др. 2013]. Также микрозаймы способствуют повышению финансовой грамотности населения. Популярность обращения в микрофинансовые организации объясняется простотой и скоростью оформления микрозаймов, что является привлекательным для определенной категории граждан. По данным ВЦИОМа, половина россиян считает эту услугу жизненной необходимостью. Больше всего микрозаймы оказались востребованными среди респондентов в возрасте $18-34$ лет (54\%), жителей села (53\%) и небольших городов $(47 \%)^{2}$. Это имеет достаточно простое объяснение. Основной причиной, по которой люди прибегают к микрозаймам, является желание получить то, чего они не могут себе позволить. Но бывают случаи, когда люди

\footnotetext{
1 Федеральная служба государственной статистики: [сайт]. Доступ: https://rosstat.gov.ru
}

2 ВЦИОМ: «Займы до зарплаты»: потребность, преимущества, риски. 24 апреля 2018 г. 
обращаются в микрофинансовые организации из-за тяжелого финансового положения.

Тем не менее микрофинансирование имеет свои минусы. Например, высокая процентная ставка, размер штрафа за просроченный платеж, риск попасть в долговую яму, деятельность коллекторов, а также то, что не все микрофинансовые организации официально зарегистрированы. При обращении в микрофинансовые организации необходимо учитывать все риски, но если человек имеет постоянный источник дохода и берет в долг небольшую сумму на кратковременный период, то опасность такого займа фактически равна нулю. Стоит учитывать то, что никто не застрахован от финансовых потрясений, которые могут значительно повлиять как на конкретного индивида, так и на общество в целом. К наиболее распространенным видам финансовых потрясений можно отнести снижение заработной платы, вынужденную безработицу, банкротство, потерю накопленных сбережений, финансовые неудачи, потерю занимаемой должности, кризис.

Финансовые потрясения в определенной степени могут повлиять на каждого человека. Так, например, пандемия коронавирусной инфекции нанесла огромный ущерб экономике России, а долги россиян перед микрокредитными организациями достигли рекордных значений. Бюро кредитных историй «Эквифакс» сообщило, что просрочка превысила $40 \%$ после месяца самоизоляции и достигла рекордного уровня. По итогам апреля клиенты микрофинансовых организаций просрочили более чем на 3 месяца выплаты по 4,5 млн займов 1 .

Так или иначе взятие кредитных обязательств влияет на человека. Он постоянно испытывает чувство страха перед неплатежеспособностью, безработицей и т.д. Человек находится в состоянии продолжительного стресса, из-за которого может терять способность справляться со сложными ситуациями.

Преодоление финансовых трудностей основывается на совершении определенных действий. Можно выделить следующие типы социального поведения в условиях невозможности выплаты займов микрофинансовым организациям:

1) индивид осознает свое финансовое положение и ищет пути решения, основываясь на общепринятых нормах;

2) индивид находится в безвыходной для него ситуации и не видит рационального решения проблемы.

Во втором случае человек фокусируется на финансовой проблеме, полностью подчиняется ей. И вот она уже кажется нерешаемой, что можно отнести к факторам возникновения девиантного поведения.

В современном российском обществе наиболее часто встречаются такие формы проявления социально-негативной девиации при условии невозможности выплат микрофинансовым организациям, как преступность, алкоголизм, наркомания, самоубийство [Гилинский 1991]. Все перечисленное препятствует гармоничному социально-экономическому развитию страны, поскольку девиантное поведение причиняет вред личности и обществу, а также нарушает общепринятые социальные нормы.

Преступность является крайней степенью социально-негативного девиантного поведения, поскольку ставит под угрозу интересы социальных институтов и общества в целом [Гилинский 1991]. Социологическая характеристика преступности проявляется в зависимости от социальных организаций, институтов, структур. Это позволяет дать оценку преступному поведению и выявить зависимость преступности от социальных процессов.

\footnotetext{
1 Долги по микрозаймам растут. - Бюро кредитных историй Эквифакс. Доступ: https:// online.equifax.ru/fin/article/id/2493/ (проверено 04.03.2021).
} 
Существуют люди, которые совершают преступления, находясь при этом в долговой яме перед микрофинансовыми организациями, например ограбление, убийство, различного рода мошенничества и др. В данном случае проявляется желание удовлетворить свои потребности, а именно избавиться от долговой зависимости.

Преступность является самой опасной формой девиантного поведения, поскольку она способствует ухудшению социально-экономической ситуации в обществе и направлена против интересов общества и личных интересов граждан [Афанасьев, Гилинский 1996].

Следствием долговых обязательств перед микрофинансовыми организациями являются стресс и негативные эмоции [Мамута 2010:11]. Продолжительный стресс истощает организм и может привести к довольно серьезным проблемам. Для снижения уровня стресса большинство людей используют алкоголь. Интоксикация алкоголем является самым легким способом снятия напряжения и страха перед усугублением финансовой ситуации. Люди, у которых нет склонности к алкогольной зависимости, когда сталкиваются с финансовыми трудностями, пытаются найти пути решения проблемы, а не начинают пить. В свою очередь, больные люди, которые склонны к алкоголизму, в данной ситуации могут начать активировать это качество и злоупотреблять алкоголем.

По данным Минздрава, финансовые потрясения вследствие пандемии коронавирусной инфекции способствовали увеличению потребления алкоголя в России на 2-3\%. Повышенный спрос на алкоголь вызван стрессом и попыткой таким образом уйти от финансовых проблем, что является ошибочным представлением о целебном действии алкоголя, поскольку существенную роль в развитии алкогольной зависимости играет воспитание, уровень образования, культуры, факторы среды, в которой формируется личность.

Социальные последствия алкоголизма весьма серьезны. Он является причиной психических болезней, несчастных случаев и преступлений. По данным Генеральной прокуратуры РФ, почти каждое третье преступление (30,6\%) совершено в состоянии алкогольного опьянения $(32,4 \% \text { в } 2018 \text { г.) })^{1}$.

Что касается наркомании, то, по данным проекта стратегии государственной антинаркотической политики РФ, число респондентов, потребляющих наркотики как регулярно, так и эпизодически, оценивается в 1,9 млн чел., или 1,3\%. Точную статистику вести невозможно, поскольку зачастую люди скрывают употребление запрещенных веществ из-за карательной наркополитики. Некоторые начинают употреблять наркотики из-за психологической травмы, неудовлетворенности жизнью, депрессии и др., в т.ч. из-за желания забыть о финансовых проблемах. Попытка уйти от трудностей путем употребления наркотиков еще больше усугубляет ситуацию. Человеку, находящемуся в долгах, необходимы финансы для удовлетворения своей негативной потребности, что может привести к еще большему объему долгов и, как следствие, к совсем безысходной ситуации.

В России процент самоубийств, совершенных из-за кредитного или другого финансового долга, довольно велик. Так или иначе кредитные обязательства влияют на человека. Зачастую микрофинансовые организации пользуются услугами коллекторов, которые оказывают психологическое, а иногда и физическое давление на человека. Люди нередко вынуждены в одиночку противостоять агрессии со стороны сборщиков долгов, находясь при этом в постоян-

1 Статистические данные о зарегистрированных преступлениях на территории Российской Федерации в первом полугодии 2019 года. - Генеральная прокуратура РФ. Доступ: http://genproc.gov.ru/smi/news/genproc/news-1670322/ (проверено 04.03.2021). 
ном страхе, из-за которого они теряют способность справляться со сложными ситуациями. Сознание человека полностью подчиняется финансовой проблеме, и именно чувство безысходности может подтолкнуть к самоубийству.

В России нет официальной статистики кредитных самоубийств, но есть возможность установить причинно-следственную связь между наличием у человека долгов по кредитным займам и актом самоубийства. Официально эту связь можно подтвердить только при наличии предсмертной записки. Согласно данным Росстата, на 2018 г. смертность по причине самоубийства составляет 18206 тыс. чел. ${ }^{1}$ Также Россия входит в число государств с самым высоким показателем самоубийств на душу населения. В группе риска находятся мужчины, поскольку они заканчивают жизнь самоубийством в 7 раз чаще, чем женщины.

Как уже говорилось выше, микрофинансовые организации могут предоставить кредит людям с плохой кредитной историей, которые имеют схожие характеристики. Например, они откладывают решение сложных проблем, не видят реальных сложностей, инфантильны, не требовательны к себе, не могут просчитать все риски. Такие люди могут совершить самоубийство из-за долговых обязательств в состоянии аффекта, когда думают, что находятся в безвыходном положении.

Таким образом, девиантное поведение индивида в ходе взаимодействия с микрофинансовыми организациями влияет на социально-экономическую ситуацию в обществе, нравственные устои, безопасность и благополучие граждан. Преступления как наиболее острая форма социально-негативной девиации представляют угрозу стабильности и безопасности страны. Преступность оказывает социальное влияние на общество, а борьба с ней является сложной проблемой.

Социально-негативная девиация способна привести общество к деградации и снижению уровня жизни отдельных категорий граждан. На данный момент эта проблема приобрела особую остроту в условиях сложной экономической ситуации в стране. Ухудшение социальных условий жизни становится причиной долговых обязательств перед микрофинансовыми организациями и, как следствие, увеличения масштабов девиации.

\section{Список литературы}

Афанасьев В.С., Гилинский Я.И. 1996. Девиантное поведение в условиях тотального кризиса: особенности, тенденции, перспективы. - Образ мыслей и образ жизни: сборник статей. М.: ИС. С. 147-162.

Гилинский Я.И. 1991. Социология девиантного поведения как социологическая теория. - Социс. Социологические исследования. № 4. С. 72-78.

Криворучко С.Г., Абрамова М.Л., Мамута М.Я., Тенетник О.Б., Шакер И.Н. 2013. Микрофинансирование в России: практическое пособие. М.: Юрайт, ИД «Юрайт». 327 с.

Мамута М.В. 2010. Микрофинансирование следует спросу на кредиты, а не создает его. - Mикроfinance+. № 4(5). С. 10-13.

\footnotetext{
1 Федеральная служба государственной статистики: [сайт]. Доступ: https://rosstat.gov.ru
} 
EPKHIEV Oleg Muratovich, Cand.Sci. (Soc.), Senior Lecturer at the Department of Sociology, Faculty of Social Sciences and Mass Communications, Financial University under the Government of the Russian Federation (49 Leningradsky Ave, Moscow,GSP-3, Russia, 125993; ephiev@fa.ru@fa.ru)

DAVIDENKO Valeriya Alekseevna, student of the Faculty of Social Sciences and Mass Communications, Financial University under the Government of the Russian Federation (49 Leningradsky Ave, Moscow, GSP-3, Russia, 125993; davidenko.valeriya@list.ru)

\title{
DEVIANT BEHAVIOR OF AN INDIVIDUAL AS A RESULT OF INTERACTION WITH MICROFINANCE ORGANIZATIONS
}

Abstract. The article discusses certain risks of taking loans at microfinance organizations in the event of financial shocks. The question of the consequences of microloans is relevant, since they can lead to various forms of deviant behavior of the individual, which significantly affect the socio-economic situation in society.

Keywords: deviant behavior, credit loans, microfinance

МАСЛЕННИКОВА Елена Викторовна - кандидат социологических наук, доцент; заведующий кафедрой государственного и муниципального управления Государственного университета управления (109542, Россия, г. Москва, Рязанский пр-кт, 99; ev_maslennikova@guи.ru); ведущий научный сотрудник центра технологий государственного управления Института прикладных экономических исследований Российской академии народного хозяйства и государственной службы при Президенте РФ (119571, Россия, г. Москва, пр-кт Вернадского, 82; maslennikova-ev@ranepa.ru) ДОБРОЛЮБОВА Елена Игоревна - кандидат экономических наук, ведущий научный сотрудник центра технологий государственного управления Института прикладных экономических исследований Российской академии народного хозяйства и государственной службы при Президенте РФ (119571, Россия, г. Москва, пр-кт Вернадского, 82; dobrolyubova-ei@ranepa.ru)

\section{РЕФОРМИРОВАНИЕ КОНТРОЛЬНО- НАДЗОРНОЙ ДЕЯТЕЛЬНОСТИ: РЕЗУЛЬТАТЫ С ТОЧКИ ЗРЕНИЯ ГРАЖДАН И СОГЛАСНО СТАТИСТИЧЕСКОЙ ОТЧЕТНОСТИ}

\begin{abstract}
Аннотация. В статье проводится сопоставление официальных статистических данных о показателях результативности и эффективности контрольно-надзорной деятельности федеральных органов исполнительной власти и данных социологических исследований о восприятии гражданами уровня своей защищенности от рисков (угроз) от деятельности подконтрольных (поднадзорных) государству субъектов. Авторы делают вывод о недостаточной объективности представленной в статистических источниках информации и о необходимости доработки методики оценки результативности и эффективности государственного контроля (надзора) для учета мнений граждан как конечных бенефициаров.

Ключевые слова: государственный контроль, надзор, защита охраняемых законом ценностей, подконтрольные (поднадзорные) субъекты, риск-ориентированный подход
\end{abstract}

тартом реформы государственного контроля (надзора) можно считать утверждение программы «Реформа контрольной и надзорной деятельно- 